\title{
Guns, Economic Growth and Education during the second half of the Twentieth Century: Was Spain different?
}

\section{Complutense de Análisis Económico}

\author{
J osé J urado-Sánchez \\ Department of Economic History and Institutions I \\ Complutense University of Madrid
}

J uan-Ángel J iménez-Martín

Department of Quantitative Economics

Complutense University of Madrid

\begin{abstract}
In the past decades, numerous studies have been conducted on the trade-off between guns and butter, namely defense versus social sector expenditure. The aim of this research is identifying whether indeed defense spending crowded out investment and other social expenditures as health and education. Previous research does not yield strong and unambiguous evidence of neither positive nor negative effects of military expenditure on social spending. It is striking that the guns versus butter dilemma has not been extensively studied for Spain. Using Mintz and Huang (1991) strategy applied to the US, we test if the government expenditure in defense in Spain during the last part of the Franco's dictatorship and the first years of the transition and democracy, contributed positively or negatively to education spending. Results show a negative trade-off for the Franco's regimen and an ambiguous effect for the last part of the sample
\end{abstract}

Keywords: Guns versus butter dilemma.

J EL: H51, H52, H53, H56, N40, N44

\section{ICAE WP \# 1414}

June, 2014 


\title{
Guns, Economic Growth and Education during the second half of the Twentieth Century: Was Spain different?
}

\author{
José Jurado-Sánchez \\ Department of Economic History and Institutions I \\ Complutense University of Madrid \\ Juan-Ángel Jiménez-Martín 1 \\ Department of Quantitative Economics \\ Complutense University of Madrid
}

June 2014

\begin{abstract}
In the past decades, numerous studies have been conducted on the trade-off between guns and butter, namely defense versus social sector expenditure. The aim of this research is identifying whether indeed defense spending crowded out investment and other social expenditures as health and education. Previous research does not yield strong and unambiguous evidence of neither positive nor negative effects of military expenditure on social spending. It is striking that the guns versus butter dilemma has not been extensively studied for Spain. Using Mintz and Huang (1991) strategy applied to the US, we test if the government expenditure in defense in Spain during the last part of the Franco's dictatorship and the first years of the transition and democracy, contributed positively or negatively to education spending. Results show a negative trade-off for the Franco's regimen and an ambiguous effect for the last part of the sample.
\end{abstract}

Keywords: Guns versus butter dilemma, military spending, economic growth and social expenditures, education spending, Spain from 1950 to 2000

JEL codes: H51, H52, H53, H56, N40, N44

\footnotetext{
${ }^{1}$ This author acknowledges financial support from the Ministerio de Ciencia y Tecnología of Spain through the research project ECO2012-31941.
} 


\section{Introduction}

The relationship between military and welfare efforts by states and its economic and social effects during the twentieth century has often been examined in the past five decades. One of the most relevant approaches to study it has been the guns versus butter hypothesis, which is generally used as a simplification of national spending as a part of GDP. This theory is the classic example of the production possibility frontier and models the relationship between the spending of a country in military and civilian goods. Nations cannot have everything they want, being limited by the resources and the technology available to them. They are always being compelled to choose between two options when spending their finite resources. They will have to decide what level of defense and civilian goods best fulfills their needs. They can buy either guns or butter, or a mix of both, every choice having an opportunity cost: they can get more of something only by giving up something else (Samuelson, 1948).

The existence or not of a trade-off relationship between military outlays and welfare spending and its economic and social effects have received substantial coverage in the academic literature, especially in the Anglo-Saxon world. Most of them focused on the short-term or direct impact of defense outlays on welfare expenditures. Others have usually assumed that this impact is indirect or long-term in nature. In spite of the diversity of approaches, theories, methodologies, and data sets used, the literature indicates that the results are inconsistent and that we do not yet know whether guns come at the expense of butter. The results of research on the guns versus butter dilemma have depended on the formulation of the hypotheses, the budgetary trade-off categories taken into account, the influential factors on resource allocation considered, the specification, estimation techniques and methodologies utild, the design of crosssectional or longitudinal approach, the solution to statistical problems such as multicolinearity and autocorrelation, the effects considered (aggregated or disaggregated), and last but not least the period examined (wartime or peacetime) and the use of actual, final or partial budgetary data (Berry and Lowery, 1990; Huang and Mintz,1992; Jurado-Sánchez,2012).

The guns-butter trade-off is a remarkable topic in Public Economics, Defense Economics and Political Science which has been analyzed for about thirty countries. The majority of them are European countries, 16 being currently members of the European Union (see Appendix 1), which represent the geopolitical environment of 
Spain. In addition, most of the previous studies analyze the second half of the $20^{\text {th }}$ century, a period in which Spain was accelerating its economic and political convergence with Europe. According to statistics published by Eurostat, between 1960 and 2000, the annual average rate of growth of Spanish GDP was close to 4.5 per cent, one percentage point more than that of the EU-15, the Spanish GDP per capita reaching 81 per cent of UE-15 figure in the 1990s. These are good reasons why this article must be written, but there exist several more. In the first place, as far as we know, the gun versus butter theory has not yet been investigated for Spain. Secondly, this research will enable us to discover the Spanish case and to compare it with the most important Western nations, that is to say, to establish whether Spain was different in spending its resources on military and civilian goods. In addition, the interest of this study increases due to the guns versus butter dilemma is an issue which is closely connected to Public Finances, which nowadays present large shortfalls in Spain and many other Western countries. Lastly, the literature of the guns versus butter theory shows that it is necessary to choose in order to finance the diverse public goods or services, this decision having important economic and social effects. For example, the provision of welfare programs implies a lot of public spending with important economic effects, but social expenditures can be a counterbalancing factor which compensates for the effects of poverty and inequality and therefore reduces the probability of social unrest.

There are in the literature several diverse and suggestive empirical models to study the existence or non-existence of budgetary trade-offs between defense and welfare expenditures. Bearing in mind the theoretical and methodological basis and other factors, we have used probably the most appealing of them for researching topics of Public Economics, Defense Economics and even Economic History. We are referring to the indirect effect model applied by Mintz and Huang (1991) to the US case from 1953 to 1987.For these authors, increased defense outlays crowd out investment, which, in turn, dampens economic growth, thereby reducing the ability of governments to allocate more funds to welfare programs. Applying the indirect effect model, we intend to discover if during the 1950-2000 period the Spanish government expenditure on defense had a positive or negative effect on education spending.

The remainder of the paper is organised as follows. In Section 2 a brief overview of the literature on the guns vs. butter dilemma is presented. Section 3 describes briefly the empirical model used in the paper. Section 4 introduces variables and data. Section 
5 presents the main results and Section 6 gives some concluding comments and proposes issues for future research.

\section{Guns versus butter theory: an overview of the literature}

Early studies of the guns versus butter dilemma, made at the end of the 1960s and in the first half of the 1970s, report the existence of a trade-off between guns and butter asserting that spending on defense comes at the expense of the welfare expenditures. The time-series analysis of Pryor (1968) for the 1950-1962 period revealed that in those countries (Canada, Greece, Federal Republic of Germany, United Kingdom and the United States) where military spending is a relatively large percentage of the public budget and the GDP, there were statistically relevant trade-offs between defense and public expenditures when transfer payments are excluded. Russet $(1969,1970)$ found that defense spending diverts resources available for private consumption and investment and several public expenditures in the United States (1939-1968), Canada, France and the United Kingdom (1947-1965). According to him, increases in defense spending led to decreases in personal consumption expenditures, fixed investment spending and in state and local USA governments' welfare, education and health spending.

Nevertheless, for Hollenhorst and Ault (1971) the impact of US military expenditures on economy and welfare spending varied substantially between the various sub-periods of war and peace contained in the 1939-68 period. These scholars believe that during the greater wars probably all society contributed to finance defense, while in the lesser wars it was the consumer who paid nearly the whole bill for military spending. Szymansky (1973) also found a negative relationship between defense spending and rates of growth of GNP and, with some important exceptions, unemployment in 18 industrialised countries during the 1950s and the 1960s, especially in those with the highest military expenditure/GNP ratios. According to Hartman (1973), the evidence suggests that defense spending in the twentieth-century United States had an inverse relationship to the general consumer's standard of living, corporate profit, balance of payments, investment and state and local government expenditures in health, education and welfare. Wilensky (1975) studied sixteen industrialised nations and showed that those countries with very high defense spending, 
military and welfare were mutually exclusive goals, especially during the Cold War period. Peroff (1976) focused her analysis on tradeoffs between defense programs and three domestic public policies and found that the welfare program most undermined by military spending was public aid, following by the health expenditures in all levels of government and housing. Smith (1977) asserted that between 1960 and 1970 in 15 advanced capitalist economies high military spending is associated with much lower investment, lower rates of economic and productivity growth and higher rates of unemployment. For Smith (1980) military spending had a clear negative effect on investment in the 14 largest OECD countries during the 1954-1973 period, this result being the main opportunity cost of defense.

From the middle of the 1970s onwards, most of the scholarly literature published found no evidence for guns versus butter trade-offs. The research of Caputo (1975) compared expenditure decisions in Australia, Sweden, the United Kingdom and the United States in defense, health and education from 1950 a 1970. This author concluded that increased defense spending does not lead to a decrease in health expenditures and that there was a trade-off between military and education and expenditures, but it was not statistically significant. Clayton (1976) affirmed that in the United States from 1900 to 1975 there has not been a significant correlation between defense and social spending since the Korean conflict, but large wars did have a notable negative impact on welfare spending. Peroff and Podolak-Warren (1979) found that in the United States from 1929 to 1974 the evidence points to no trade-off between federal health and defense in allocations or final expenditures during war or peace, although a tradeoff existed between the private health sector and defense only in terms of capital investment in health. For Russet (1982) in the United States from 1941 through 1979 defense spending tended most often to move in the same direction as health or education expenditures, these three budgetary items increasing simultaneously during the greater part of the examined period. Domke, Eichenberg and Kelleher (1983) examined spending patterns from 1948 to 1978 in the United States, United Kingdom, Federal Republic of Germany, and France. They showed the absence of systematic defense/welfare trade-offs for most of the period since World War II, and asserted that military outlays and spending on welfare are unrelated. In the words of Mintz (1989), previous research on guns vs. butter tradeoffs have focused on total military spending and specific kinds of welfare expenditures (education, health, housing...). He expanded 
the analysis to include the major subcomponents of the USA defense budget, i.e., military personnel, military procurement, operation and maintenance and research and development. The results of the disaggregated analysis by Mintz have likewise shown a lack of defense-welfare trade-offs, except in the Reagan era.

Berry and Lowery (1990) criticised existing investigation on budgetary tradeoffs on several theoretical and methodological grounds, describing 'the empirical results... as mixed' (p.693). But they also found only limited empirical support for the domestic-defense trade-off (i.e. guns versus butter trade-off) in the United States from 1949 through 1983. Mintz and Huang (1991) believe that one reason why investigations of the guns vs. butter dilemma seem to be partially supported in the empirical literature may be because only the direct budgetary trade-off between defense and welfare expenditures have been examined, usually assuming that the relationship between both kinds of outlays is zero-sum and, therefore, the direct effect of the former on the latter is expected to be negative. It is possible, however, these scholars assert, that military expenditure may have an indirect, negative effect on social spending, given that increased defense outlays crowd out investment, which, in turn, reduces economic growth, thereby diminishing the capacity of governments to allocate more funds to welfare programs. This indirect tradeoff, Mintz and Huang conclude, existed in the US during the 1953-1987 period, needed about six years to take place and reduced the education spending made by federal governments. Mok and Duval (1992) studied the expenditures on defense and welfare in the United States from 1954 to 1986. They found fairly strong evidence for the existence of certain trade-offs between defense and several civil programs (income security, energy, agriculture...), but other fail to produce a significant negative relationship (education and social security), while health and Medicare in fact produce a significant positive relationship with defense spending. Yildirim and Sezgin (2002) suggest that in Turkey from 1924 to 1996 there were tradeoffs between military and welfare spending, being negative between defense and health and positive between defense and education. These results support the idea that increased military expenditures reduce the resources available for health, but also suggest that defense does not crowd out education. Gifford (2006) believes that the inconsistent findings of empirical research on the guns vs. butter dilemma are due to the standard measure of military efforts utilised -military outlays- not being good enough to capture the whole impact of defense. For this reason, he analyses both defense spending 
and military personnel as a more wide-ranging measure of a state's defense in a study of 16 developed and industrialised nations from 1960 to 1993. Gifford concludes that countries with large armed forces relative to their populations make smaller social welfare efforts, while nations with conscription tend to spend more on social programs.

\section{Direct, indirect effect or both: Mintz and Huang model}

The academic literature put at our disposal many different approaches, models and methods to study the relationships between defense outlays and welfare spending in Spain. Some of them are quite revealing, notably those of Russet (1982), Domke, Eichenberg and Kelleher (1983), Barry and Lowery (1990), Mok and Duval (1992), and Gifford (2006). Nevertheless, taking into account the theoretical and methodological fundamentals, the data availability for Spain and other factors, it seems that one of the most appealing to carry out a research on a topic of Public Economics, Defense Economics and even Economic History is the indirect effect model by Mintz and Huang (1991).These authors hypothesise, firstly, that when military expenditures increase, investment is reduced. This trade-off is due to military spending and investment competing for the non-consumption part of the total productive capacity of the economy and to private and non-military public consumption accounting for more than half of the total output of the economy with both being highly resistant to reductions. In addition, increased levels of defense outlays may also entail higher taxes or government borrowing, funds that otherwise might have gone to investment. Secondly, they expect, so long as investment is a crucial element of economic growth, that military spending will have a negative, indirect effect on growth. Lastly, they also suppose that the link between economic growth and education spending is positive, given that the former propelled the expenditures in all government programs, including the latter.

Mintz and Huang propose a three-equation system to analyze both direct and indirect effects of military exp enditure on welfare programs: on the one hand, the direct effect, namely the high opportunity costs of military expenditure from a socio-economic point of view, since scarce resources are absorbed that could otherwise have been utilised more effectively in education endeavor; on the other hand, they include in the analysis the indirect effect through the crowding-out effect of military spending on investment to reflect the fact that military spending may reallocate potential private and public expenditure away from investment, thereby reducing economic growth, and 
consequently negatively affecting to welfare expenditure. We follow the model specification of Mintz and Huang (1991) to analyze the next three effects:

i) They first specify an equation that defines investment as a function of several private and government spending variables, including defense expenditure. This model can be used for identifying the direct impact of military spending on investment.

Mintz and Huang's investment and defense equation comes from the flexible accelerator model proposed by Clark (1917) and then modified by Koyck (1954) and Chenery (1952) that considers gross investment, $I$, as a distributed lag on production, $Y$, and depreciation, approximated by a proportion of the capital stock, $K$. Therefore,

$$
I_{t}=\sum_{s=0}^{\infty} \beta_{s} \Delta Y_{t-s}+d K_{t-1}
$$

Where $\Delta$ is the difference operator. National accounting states that $Y_{t}=C_{t}+I_{t}+G_{t}+N X_{t}$, where $\mathrm{C}$ is consumption, $N X$ are net exports (exports-imports), $G$ is the government purchases of goods and services. Assuming that $G_{t}=M_{t}+N M_{t}$, where $M$ is military spending and $N M$ is non-military outlays and $P_{t}=C_{t}+I_{t}+N X_{t}$, where $P$ is production in the private sector, then:

$$
Y_{t}=P_{t}+N M_{t}+M_{t}
$$

We can divide each side of (1) by $Y$, that is, every variable is going to be a proportion of the GDP. Plugging (2) in (1), assuming a finite number of lags and including a random error, equation (1) can be written as a testable equation:

$$
\frac{I_{t}}{Y_{t}}=\beta_{1}^{I}+\sum_{s=1}^{n} \beta_{p, s}^{I} \frac{\Delta P_{t-s+1}}{Y_{t}}+\sum_{s=0}^{n} \beta_{N M, s}^{I} \frac{\Delta N M_{t-s+1}}{Y_{t}}+\sum_{s=0}^{m} \beta_{M, s}^{I} \frac{\Delta M_{t-s+1}}{Y_{t}}+\beta_{k, 1}^{I} \frac{K_{t-1}}{Y_{t}}+u_{t}^{I}
$$

ii) The indirect effect of military expenditure on growth is analyzed through an equation that allows the crowding out effect to be measured. 
The relationship between $I, M$ and other variables accounting for economic growth, comes from the Solow (1988) and Denison $(1967,1985)$ models that link economic growth to changes in the level of capital and employment. Ram (1986) extends these models: on the hand he introduces the government output on it, and on the other hand assumes a linear relationship among these variables:

$$
\frac{\Delta Y_{t}}{Y_{t-1}}=\alpha \frac{I_{t}}{Y_{t-1}}+\pi \frac{\Delta L_{t}}{Y_{t-1}}+\theta \frac{\Delta G_{t}}{Y_{t-1}}
$$

where $L$ is the civilian labor force and all other definitions are as above. Taking into account that $G=M+N M$, equation (4) can be written as:

$$
\frac{\Delta Y_{t}}{Y_{t-1}}=\beta_{1}^{Y}+\beta_{2}^{Y} \frac{I_{t}}{Y_{t-1}}+\beta_{3}^{Y} \frac{\Delta L_{t}}{Y_{t-1}}+\beta_{4}^{Y} \frac{\Delta N M_{t}}{Y_{t-1}}+\beta_{5}^{Y} \frac{\Delta M_{t}}{Y_{t-1}}+u_{t}^{Y}
$$

In equation (5) we can test both the direct and indirect effect of military expenditure on growth. $\beta_{2}^{Y}$ and $\beta_{5}^{Y}$ represent the indirect and the direct effect on growth of changes in military spending, respectively.

iii) Finally, the direct and indirect effect of military spending on education can be analyzed through the education expenditure equation.

Following Russet (1982), Mintz and Huang (1991) propose a linear relationship among changes in education expenditure $\left(\Delta E d u Y_{t}\right)$ and growth $\left(\% \Delta Y_{t}\right)$ and changes in military spending $\left(\% \Delta M Y_{t}\right)$, government revenues $(T)$ and school enrolment $\left(\% \Delta\right.$ Enrol $\left._{t}\right)$ :

$$
\% \Delta\left(E d u Y_{t}\right)=\beta_{1}^{E d u y}+\beta_{2}^{E d u y}(\% \Delta Y)_{t}+\beta_{3}^{E d u y}\left(\% \Delta M Y_{t}\right)+\beta_{4}^{E d u y}\left(\Delta \% T Y_{t}\right)+\beta_{5}^{E d u y}\left(\% \Delta E n r o l_{t-1}\right)+u_{t}^{E d u c y}
$$

Where \% $\Delta$ stands for percent change and $E d u Y_{t}, M Y_{t}, T Y_{t}$ are the ratios of education and military expenditures and government revenues to GDP respectively. Equation (6) represents the main tool for understanding both the direct and indirect effect. On the one hand, if a crowding out effect is found along with a statistically significant $\beta_{2}^{\text {Eduy }}$ parameter, it implies an indirect effect of military expenditure on education. On the other hand, if $\beta_{3}^{E d u y}$ is statistically significant and positive it means that military 
spending encourages education expenditure. The total effect will be depend on the size of $\beta_{2}^{\text {Eduy }}$ and $\beta_{3}^{\text {Eduy }}$.

In short the trade-off between guns and butter would require:

1. Negative estimate for parameters $\beta_{M, s}^{I},(\mathrm{~s}=1, \ldots, \mathrm{k})$ in equation (3), which would suggest the Crowding-out effect of defense expenditures

2. Positive values of $\beta_{2}^{Y}$ in equation (5), showing the indirect impact of increasing military spending on growth through decreasing investment.

3. Finally, both direct and indirect effect can be tested in equation (6). A statistically significant and positive $\beta_{2}^{\text {Eduy }}$ coefficient would mean that if a crowding-out effect on investment exists a higher military burden will reduce education spending through lower growth. In addition, a statistically significant and negative $\beta_{3}^{\text {Eduy }}$ parameter, capturing the direct effect, would imply that the higher the military spending the lower the resources available for enhancing education expenditure.

Finding direct and indirect effects of military expenditure on education will involve estimating equations (3), (5) and (6), which represent a system of three linear regressions that can be individually estimated by OLS assuming that their disturbances are not correlated. Alternatively, one could think that equation errors are likely to be subject to correlated spillovers from economy-wide shocks. For the latter case, using the seemingly unrelated regression (SUR) may provide more efficient estimates by combining information on different equations (Zellner, 1962).

\section{Data description}

We use annual data from 1950 to 2000 of gross private domestic investment (I), gross domestic product at market prices $(\mathrm{Y})$, private business output $(\mathrm{P})$, military $(\mathrm{M})$, nonmilitary (NM), central and regional government education expenditure (Edu) and government revenues (T). All these data are measured in millions of constant 1995 Spanish Pesetas. In addition, we have data of net value of capital stock in millions of constant 1990 Spanish pesetas (K), school enrolment (Enrol) and employed civilian labor force (L) (see Appendix 2 for a precise source description). 
In Figure 1 the performance of the abovementioned ten variables is seen. Six of them show long run positive trend during the whole period studied $(K, P, Y, T)$ or the most part of it $(M, N M)$. Military expenditure drops considerably from the late 1980s until the mid-1990s and then stays stable, this probably being due to the fact that in a democratic system both the preferences of average voter and the demands for social spending diminish the allocation of money to defense efforts (Goldsmith, 2003; Sprout and Sprout, 1968). Investment and employed civilian labour force increased until the middle of the seventies, then stagnated or decreased till the mid-1980s, and increased again for the rest of the period or the greater part of it. The causes of stagnation and decrease of investment were probably the economic crisis of the 1970s and the political instability generated in Spain during the transition to democracy. As for school enrollment, it grew until 1987, with the exception of the first half of the 1960s and the first years of the 1970s, and then decreased during the 1990s. This drop might be explained because from 1977 onwards the birth rate fell at a faster rate than it did in any other country in Western Europe, putting an end to Spain's 'baby boom'. As a result, the school population pressures of the 1960s and the 1970s would soon abate, giving the country's educational system some much-needed breathing space. Lastly, regarding education spending, the positive trend stopped in 1978, and then it stagnated during the following three years, decreased in 1982-1986 and finally experienced a vigorous growth from 1987 onwards with the exception of 1992-1994. Public Education expenditures begin to grow strongly after the implementation in 1970 of the General Education Law (Ley General de Educación). The negative impact that the educational system had on human capital formation and economic growth during the first decades of Franco dictatorship was only overcome step by step. In the period 1940-1960, several factors led to a considerable loss of human capital, which negatively affected growth. We are referring to the decline of duration of schooling, forced emigration of democratically minded intellectuals, professors and teachers, and so on. In spite of increasing public education expenditures from 1970 on, at the end of the Franco regime education spending was characterised by low public financing (Camps, 2013). Probably, the stagnation and reduction of education spending during the transition to democracy was due to the second oil crisis (1979-1982) and the cuts in public spending implemented in the following years to tackle it. The economic recovery from 1986 onwards, driven by the integration of Spain in the European Economic Community, 
made it possible for total public spending, including education expenditures, to increase strongly.

Figure 2 provides four graphs of ratios. Military expenditure as a percentage of GDP decreases during the full period, reflecting that from 1950 onwards Spanish military expenditure as a percentage of GDP seems to be lower than in the main European countries (France, Great Britain) and the US, especially in the years of the Cold War. Nevertheless, military spending absorbed a very significant percentage of total state expenditure until the 1970s, surpassing the quarter two decades earlier. The contrast of this result with the lower ratio of the military burden can be explained by the underdeveloped public sector in Spain during the dictatorship, a period in which public expenditure in other countries was increasing at accelerated rates. The spending of the Spanish state as a percentage of GDP was five points lower in the 1950s than in the 1930s, decreasing to the level of the beginning of the twentieth century. (Herranz, Sabaté and Galofré-Vilà, 2011). Education expenditure as a percentage of GDP increased, with some fluctuations, till 1971, decreased during the following years, recovering in 1977 the level of 1971, only to fall again between 1979 and 1986. Subsequently, it showed high growth until 1991, fell for the following years and finally stagnated for the rest of the period studied. From the 1970s onwards, the public education spending as a percentage of GDP increased by a factor of 2.6. If in the 1950s and the 1960s it surpassed 1 per cent of GDP, in the 1980s and the 1990s it was over 3 per cent and 4 per cent, respectively. When analyzing investment and education spending as a percentage of military expenditures, we observe than the $I / M$ ratio describes a positive trend during the whole period except for the transition period, and the $E d u / M$ ratios increased until about 1972, decreased during the last years of the Franco regime, grew again between 1976 and 1979, with a fresh decrease until 1986, and finally it experienced vigorous growth for the rest of the period.

\section{Results}

Table 1 shows the individual OLS estimates for equations (3), (5) and (6). We compute robust standard errors using the Newey-West heteroskedasticity and autocorrelation-consistent (HAC) estimator. These standard errors are consistent estimates of the true standard deviations of the estimated coefficient, even if the errors are heteroskedastic and/or autocorrelated. 
Identifying direction and size of effects in equations (3), (5) and (6) is crucial in this research. Bearing in mind that the scale of the variables is not the same, it makes rather difficult to decide which of the effects of the explanatory variable on the endogenous variables are most important, since the value of the regression coefficients depends on the choice of units to measure the variables. One option to overcome this limitation would be to estimate equations using 'standardised' variables that are 'metricfree' because each standardised variable has a mean of 0 and a variance of 1 . Having standardised the variable, the interpretation of the coefficient is a straightforward: oneunit increase in an explanatory variable (i.e. 1 standard deviation change in such a variable) results, on average, in a change of $\beta^{\text {standardized }}$ in the standardised endogenous variable. Hence, using standardised coefficients one can determine whether a onestandard-deviation change in one independent variable produces more of a change in relative position than a one-standard-deviation change in another independent variable. Nowadays this proposed solution is much less popular than it used to be, mainly because the coefficients can be less intuitively meaningful. In this paper we propose a similar alternative based on identifying the response of the endogenous variables to onestandard deviation shock on every independent variable rather than one unit shocks, following the well-known procedure for computing impulse response functions in time series analysis. Standard deviation is a measure that describes the probability of an event under a normal distribution. For instance, assuming normality, one standard deviation accounts for 68 percent of all the possible cases, two standard deviations make up 95 percent of all cases, and three standard deviations cover more than 99 percent of all possible cases. Therefore, normalizing the change in variables to onestandard-deviation shocks, we are assuming changes that imply approximately the same percentage probability of happening for all the variables. In particular, if we estimate the model

$$
y_{t}=\beta_{1}+\beta_{2} x_{2 t}+\beta_{3} x_{3 t}+u_{t}
$$

Assuming that $s_{y}, s_{x_{2}}$ and $s_{x_{3}}$ are the standard deviation of $y_{t}, x_{2 t}$ and $x_{3 t}$, respectively, we interpret the model by saying that one-standard deviation change in $\mathrm{x}_{2 \mathrm{t}}$ results in a change in $y$ of $\beta_{2} \times s_{x_{2}}$, while one-standard deviation change in $\mathrm{x}_{3 \mathrm{t}}$ results in a change in $y$ of $\beta_{3} \times s_{x_{3}}$ 
This strategy has two main advantages: (1) it solves the measurement unit problem; and (2) estimating the model using the variables as defined in equations (3), (5) and (6) makes interpreting the results much easier. Following previous strategy for identifying the effects on investment of changes in military expenditure we look at equation (3), the investment equation, in which every variable (endogenous and exogenous) appears as a proportion of GDP to avoid non-stationary behavior in the errors of the model. In order to account for the autocorrelation found in the residual, we include an order 1 autoregressive model (AR(1)) that successfully captures the dependence structure. The number of lags included in the equation for the change in $\mathrm{P}$, NM and M (a choice based on their significance) were 5, 4 and 3, respectively. Military spending takes one year to have an impact on investment, but then the effect lasts for three years. In order to find out the effect on investment of private sector production, non-military and military expenditures, we analyze the impact of one standard deviation change in each of these variables rather than unit shocks. For instance, instead of tracing an unexpected unit increase in military expenditure with standard deviation of 0.0024 in the investment equation, one may follow up on a shock of 0.0024 units. The same might be done for the rest of the variables and equations. Of course, this is just a matter of rescaling the responses. In particular, after three years, we find that one standard deviation increase in private production (2.8 per cent) increases the I/Y ratio by 7.9 per cent (2.04 times the I/Y standard deviation), non-military spending decreases that ratio by 3.2 per cent ( 0.82 times the I/Y standard deviation) and finally the military spending change decreases the I/Y ratio by 2.1 per cent ( 0.55 times its standard deviation). Based on this illustrative example, one standard deviation shock on private consumption has a higher and more positive impact on investment than a one-standard deviation positive shock on government spending. Nonetheless, this result supports the military one-year delayed crowding-out effect found in Mintz and Huang (1991).

Equation (5) has as explanatory variables the change in the employment rate of the civilian labor force, absolute change in military, non-military expenditure and investment as a proportion of GDP. In addition, we include a dummy variable $\left(D_{\mathrm{t}}\right)$ that takes the value 1 from 1976 to 2000 and 0 for the rest of the sample to take into account different behavior of the several categories of public expenditure during and after the period of Franco dictatorship. We find that employment of the civilian labor force, military expenditure growth and investment have a positive impact on the GDP growth. 
It is noteworthy that the positive direct effect of investment on GDP growth during Franco regimen (20.59) is four times larger than the effect found during the Spanish transition (5.23), thus investment has a higher positive effect during the dictatorship period, than during the transition and democracy part of the sample. Probably, this was due to the Spanish economy having had during the Franco regime a higher growth potential than in the following decades because it was more backward. Surprisingly, non-military expenditure changes do not seem to have a statistically significant contemporary impact on the Spanish GDP growth.

In order to shed light on the indirect effect of military outlays on education we can analyze the effect of one standard deviation change in military spending as a proportion of GDP (0.0024). According to equation (5), one-standard deviation positive shocks on military spending would have increased GDP growth by 0.57 per cent (237.32 times 0.0024 ), which is slightly lower than the effect of one-standard deviation positive shock on investment that would increase GDP growth by 0.78 per cent (20.59 times 0.038) during the Franco regime and by 0.20 per cent (20.58-15.36 times 0.038) after Franco's dictatorship period. Therefore, the negative effect on growth because of the crowding out effect of a positive shock on military expenditure was not offset by the short run direct positive effect on the GDP growth during Franco regime. Thus, during the Franco era, our findings follow Mintz and Huang's (1991) results for the US. They did not find a statistically significant direct effect of military expenditure on growth, therefore the negative relationship between military expenditure and growth is a result of its crowding effect on investment. Indeed, we also found a positive effect of military spending in growth, although it does not offset the crowding out impact of investment. Nonetheless, during the Spanish transition to democracy, results support the 'Benoit hypothesis', which found a positive relationship between GDP growth and military expenditure in 44 less-developed countries, including Spain, a developing nation during the 1960 s and the 1970s.

Having shown that the crowding out effect of military spending reduced the GDP growth during the Franco regime, equation (6) allows us to analyze whether it also had a negative effect on education expenditure. Table 1 shows a positive two year delayed effect of the GDP growth on education expenditure. Based on previous analysis of equations (3) and (5) estimates, during the first part of the sample military spending would have a negative two-year delayed indirect effect on education. We do not find 
any contemporary direct effect. Nevertheless, following Mintz and Huang's worries about negative delayed impact of military spending on education, we introduce one lag of military spending changes in our regression. Military spending turned out to have a slight one-year direct delayed negative effect on education expenditure. In short, during the Franco regime, both the direct and indirect effect of military outlays contributed to reduce education expenditure. Finding the final effect of military expenditure in the second part of the sample is challenging due to the fact that we do not find negative consequences on growth of increasing military expenditure. Deeper analysis on the equation (6) estimation allows us to conclude that one standard deviation change in growth (3.2 per cent) has a positive impact on education expenditure change of 3.3 per cent (1.02 times 3.2 per cent), while one standard deviation change in military expenditure as a proportion of GDP (7.8 per cent) reduces education expenditure by 2.1 per cent ( 0.27 times 7.8 per cent). These results highlight the negative consequences of military spending, in particular during Franco dictatorship and support the guns versus butter trade-off. We found both, a one- year delayed direct and a three-year delayed indirect effect. Finally, increasing enrolment has a positive influence on education expenditure. Government revenues seem to have no positive influence on education expenditure.

To test the robustness of the OLS estimator we will estimate the three equations using the SUR (Seemingly Unrelated Regressions) estimator, including the same variables as for the individually estimated equations. Table 3 shows the error correlation matrix of the three equations estimated in Table 2. Errors in equations (3) and (5) might be negatively correlated, low correlation appearing between the rest of the equation errors. A cross correlogram among errors does not show any statistically significant relationship. Table 4 shows the SUR estimate for the three equations. Some slight differences are found in equation (3). Changes in non-military expenditure only have an effect on the I/Y ratio with a three year delay. The rest of the effects in equations (5) and (6) seem to be similar.

To summarise we can conclude that:

1. Military and non-military expenditure produced a crowding out effect on private investment that turned out to reduce economic growth especially during the Franco's dictatorship period. Nevertheless, military spending appears to have a moderately 
positive impact on economic growth during the transition and democracy part of the sample.

2. We found a delayed negative direct impact of military spending on education expenditure. In addition, a 2-year positive delay effect of growth is found statistically significant in explaining education spending. Therefore, both direct and indirect effects are found for the analyzed period.

3. Based on these results, the impact of increasing defense spending on education expenditure turned out to be negative during Franco's dictatorship period, since both direct and indirect effect moved in the same direction: higher military expenditure diminished investment and it brought down economic growth and consequently affected education expenditure negatively. On the contrary, for the second part of the sample, increasing defense expenditure turned out to increase growth in spite of the crowding out effect. Therefore, it would be difficult to identify the final effect on education spending. Probably it depended on the ability of the policy-makers to make spending decisions based on their implications for economic growth. It becomes clear that they must to take into account both the direct and indirect effect of defense spending.

4.- Finally, it is noteworthy that according to the average economic growth generated during the period examined (4.83 per cent) and the average reduction on military expenditure as a percentage of GDP (2.51 per cent), based on equation (6), education spending should have increased by 5.60 per cent, while the actual education spending increased by just 3.31 per cent. This could prove that Spanish governments, especially during Franco dictatorship, did not take full advantage of the exceptional conditions to increase public education spending during the analyzed period.

\section{Concluding remarks}

In this paper we analyze the defense-economic growth-education relationship for Spain in the second half of the twentieth century. Previous empirical studies on the guns versus butter dilemma made for thirty countries, most of them in Europe, reported mixed results. An influential paper by Mintz and Huang (1991) found an indirect tradeoff between military outlays and education spending through declining economic growth via reduction of investment for the US between 1953 y 1987. Applying Mintz and Huang's strategy we repeat the analysis for Spain during the period 1950- 2000. We 
find both direct and indirect effects of military spending on education expenditures, neither of them being contemporary, and contrary to the Mintz and Huang analysis that did not find the direct effect for the US. During Franco dictatorship, both effects moved in the same direction, decreasing education expenditure. For the transition to democracy, the crowding out effect was offset by the short run positive effect generated by military outlays on the GDP growth. This finding supports the conclusion of Benoit, i.e., in the countries that were less-developed, as was Spain during the 1970s, defense spending had a positive effect on the performance of the economy. This result highlights that the final impact of military outlays on education expenditure might depend on policy-maker spending decisions. It is hoped that expenditure choices by government will be one of the many important issues of Public Finance that this article gives rise to in future research.

\section{References}

Alcaide, J., dir. (2007), Evolución de la población española en el siglo XX, Madrid: Fundación BBA

Anuario Estadístico Militar, 1960-1997 (2004), Madrid: Ministerio de Defensa Anuario Estadístico Militar, 1998-2002 (2006), Madrid, Ministerio de Defensa Anuarios Estadísticos del Instituto Nacional de Estadística (www.ine.es/inebaseweb)

Benoit, E. (1973), Defense and Economic Growth in Developing Countries, Lexinton, MA: D.C. Heath

Berry, W. and Lowery, D. (1990), 'An Alternative Approach to Understanding Budgetary Tradeoffs', American Journal of Political Science, 34, 3: pp. 671-705

Camps, E. (2013), 'The Impact of Investment in Education on Economic Development: Spain in Comparative Perspective, 1860-2000’, Pompeu Fabra University, Working Papers 1373

Caputo, D. (1975), 'New perspectives on the public policy implications of defence and welfare expenditures’, Policy Science, 6, pp. 423-46

Carreras, A., Prados, L. and Rosés, J.R. (2005), 'Renta y riqueza', in A. Carreras y X. Tafunell, Estadísticas Históricas de España, siglos XIX-XX, Bilbao: Fundación BBVA

Clark, J.M. (1917), 'Business Acceleration and the Law of Demand: a Technical Factor in Economic Cycles, an Prediction’, Journal of Political Economy, 25, pp. 217-35

Clayton, J.L. (1976), 'The Fiscal Limits of the Warfare-Welfare State: Defense and Welfare Spending in the United States since 1900’, Western Political Quaterly, 29, 3, pp. 364-83 
Comín, F. and Díaz, D. (2005), 'Sector publico administrativo y estado del bienestar' in A. Carreras y X. Tafunell, Estadísticas históricas de España siglos XIX-XX, Bilbao: Fundación BBVA

Cubel, A. and Palafox, J. (2002), 'El stock de capital productivo de la economía española, 1900-1990’, Instituto Valenciano de Investigaciones Económicas, Working Paper-EC, 6,

Cuentas de las Administraciones Públicas (1958-2000), Madrid: Ministerio de Hacienda and IGAE

Chenery, H.B. (1952), 'Over-capacity and the Acceleration Principle', Econometrica, 20, pp. 128

Denison, E.F. (1967), Why Growth Rates Differ, Washington DC:, Brookings Institution

Denison, E.F. (1985), Trends in American Economic Growth, Washington DC: Brookings Institution

Domke, W., Eichenberg, R. and Kelleher, C. (1983), 'The illusion of choice: defense and welfare in advanced industrial democracies, 1948-1978', American Political Science Review, 77, 1, pp. 19-34

Gifford, B. (2006), ‘Why No Trade-off between `Guns and Butter’? Armed Forces and Social Spending in the Advanced Industrial Democracies, 1960-1993', American Journal of Sociology, 112, 2, pp. 473-509

Goldsmith, B.E. (2003), 'Bearing the Defense Burden, 1886-1989: Why Spend More?', Journal of Conflict Resolution, 47-5, pp. 551-73

Hartman, S.W. (1973), 'The Impact of Defense Expenditure on the Domestic American Economy, 1964-1972', Public Administration Review, 33, pp. 379-90

Herranz Loncán, A., Sabaté Domingo O. and Galofré-Vilà, G., (2011), 'A Long-term Comparative analysis of Spanish military expenditure (1850-2009)', ICIP Working Papers, 2011/5.

Hollenhorst, J. and Ault, G. (1971), 'An Alternative Answer to Who Pays for Defense', American Political Science Review, 65, 3, pp. 760-3

Huang, Ch. And Mintz, A. (1992), 'Guns vs. Butter: Conceptual and Methodological Issues', Policy Studies Review, 3-4, pp. 347-58

Jordana, J. and Ramió, C., ‘Gobierno y Administración’, in Carreras y X. Tafunell, Estadísticas Históricas de España, siglos XIX-XX, Bilbao: Fundación BBVA Jurado-Sánchez, J. (2012), ‘¿Se financió la defensa a costa del gasto social y la economía en el siglo XX? El dilema cañones versus mantequilla’, Hacienda Pública Española, 203, 4, pp. 89117

Koyck, L.M. (1954), Distributed Lags and Investment Analysis, Amsterdam: North-Holland 
Más M., Pérez, F. and Uriel, E. (2003), El stock de capital en España y su distribución territorial (1964-2000), Bilbao: Fundación BBVA

Mintz, A. (1989), 'Guns vs Butter: A Disaggregated Analysis', American Political Science Review, 83, 4, pp. 1285-93

Mintz, A. and Huang, Ch. (1991), 'Guns versus Butter: The Indirect Link’, American Journal of Political Science, 35, 3, pp. 738-57

Mok, J.W. and Duval, R.D. (1992), 'Guns, Butter, and Debt: Balancing Spending Tradeoffs between Defense, Social Programs, and Budget Deficits', in A. Mintz (ed.), The Political Economy of Military Spending in the United States, New York and London: Routledge

Núñez, C.E. (2005), 'Educación’, in A. Carreras y X. Tafunell, Estadísticas Históricas de España, siglos $X I X-X X$, Bilbao: Fundación BBVA

Peroff, K. (1976), ‘The Warfare-Welfare Tradeoff: Health, Public Aid, and Housing’, Journal of Sociology and Social Welfare, 4, pp. 366-81

Peroff, K. and Podolak-Warren, M. (1979), 'Does Spending On Defence Cut Spending On Health? A Time-Series Analysis of the U.S. Economy, 1929-1974', British Journal of Political Science, 9, 1, pp. 21-39

Prados de la Escosura, L. (2003), El progreso económico de España (1850-2000), Bilbao: Fundación BBVA

Pryor, F.L. (1968), Public Expenditures in Communist and Capitalist Nations, Londres: George Allen y Unwin LTD

Ram, R. (1986), 'Government Size and Economic Growth: A New Framework and Some Evidence from Cross-Section and Time-Series Data’, American Economic Review, 76, pp. 191203

Russett, B.M. (1969), 'Who Pays for Defense? ‘, American Political Science Review, 63, 2, pp. $412-26$

Russett, B.M. (1970), What Price Vigilance? The Burdens of National Defense, New Haven: Yale University Press

Russett, B.M. (1982), 'Defense Expenditures and National Well-being', American Political Science Review, 76, 4, pp. 767-77

Samuelson, P. (1948), Economics: An Introductory Analysis, New York: McGraw-Hill Smith, R.P. (1977), 'Military expenditure and capitalism', Cambridge Journal of Economics, 1, pp. 61-76

Smith, R.P. (1980), 'Military Expenditures and Investment in OECD Countries, 1954-1973', Journal of Comparative Economics, 4, pp.19-32

Sprout, H. and Sprout, M. (1968), 'The dilemma of rising demands and insufficient resources', World Politics, 20-4, pp. 660-93 
Solow, R.M. (1988), Growth Theory: An Exposition, New York: New York University Press Szymansky, A. (1973), 'Military spending and economic stagnation', American Journal of Sociology, 79, pp. 1-14

Wilensky, H. (1975), The welfare state and equality, Berkeley: University of California Press Yildirim, J. and Sezgin, S. (2002), Defence, Education and Health Expenditures in Turkey, 1924-96. Journal of Peace Research, 39:5, pp. 569-80

Zellner, A. (1962), 'An efficient method of estimating seemingly unrelated regression equations and tests for aggregation bias', Journal of the American Statistical Association, 57: pp. 348-68

\section{Appendix 1. Countries and periods studied in the literature}

Australia (1950-1993), Austria (1950-1993), Belgium (1950-1993), Bulgaria (19501996), Canada (1947-1993), Czechoslovakia (1950-1966), Denmark (1950-1993), Federal Republic of German (1947-1993), Finland (1950-1993), France (1947-1993), German Democratic Republic (1950-1966), Greece (1950-1966), Holland (1950-1993), Hungary (1950-1966), Ireland (1950-1993), Israel (1950-1968), Italy (1950-1993), Japan (1950-1993), Luxembourg (1960-1993), New Zealand (1950-1993), Norway (1950-1993), Poland (1950-1966), Romania (1950-1966), Soviet Union (1950-1966), Sweden (1950-1993), Switzerland (1950-1993), Turkey (1924-1996), United States of America (1900-1993), Yugoslavia (1950-1966).

\section{Appendix 2. Data sources used to construct series}

Gross domestic product at market prices: From Carreras, Prados and Rosés (2005)

Gross private domestic investment: Constructed with the GFCF and deflator GFCF figures from Prados (2003)

Net value of capital stock: From Cubel and Palafox (2002) and Mas, Pérez and Uriel (2003)

Private business output: Calculated subtracting from the GDP the government consumption, based on Carreras, Prados and Rosés (2005) and Prados (2003)

Military spending: From Comín and Díaz (2005)

Non-military spending: Constructed subtracting from the total state spending military expenditures, based on Comín and Diaz (2005)

Central and regional government education expenditure: Series constructed from Comín and Díaz (2005) and Cuentas de las Administraciones Públicas

Government revenues: From Comín and Díaz (2005)

School enrollment: From Núñez (2005) and Anuarios Estadísticos del Instituto Nacional de Estadística

Employed civilian labor force: From Alcaide (2007), Jordana (2005) and Anuario Estadístico Militar, 1960-1997 and 1998-2002) 
FIGURE 1

Time series
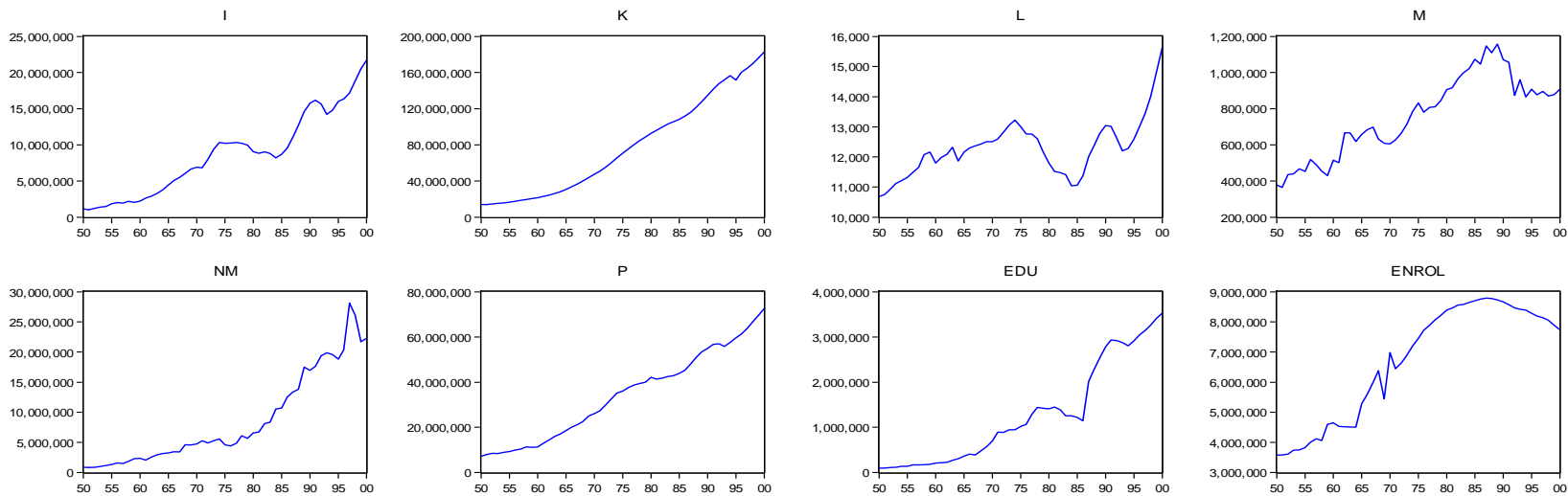

EDU
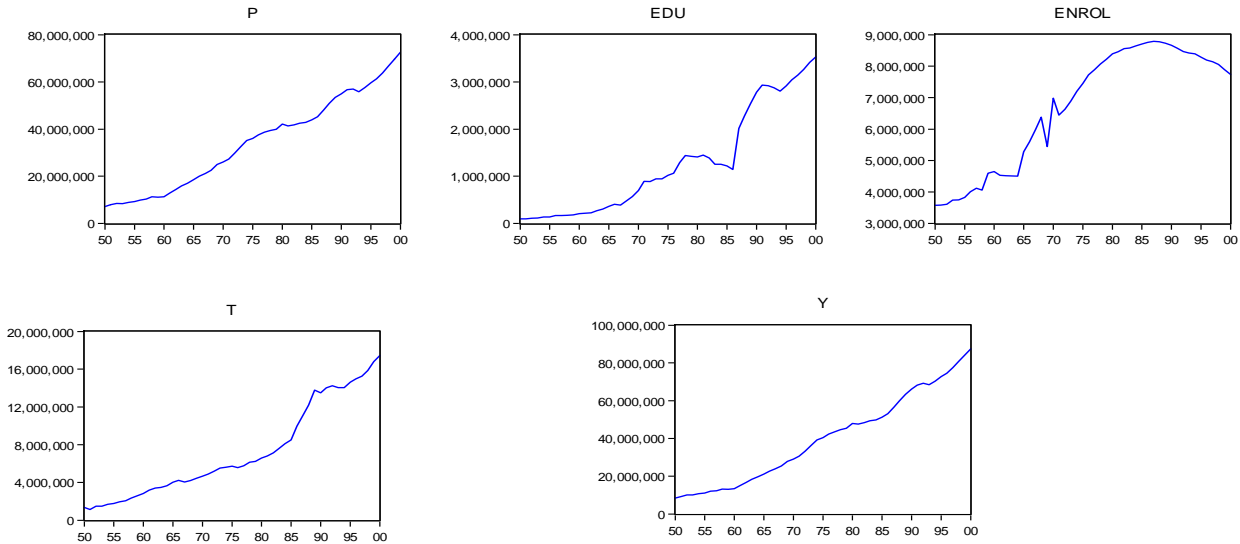

FIGURE 2

Military spending/ GDP, education spending/GDP, investment/military spending and education spending/military spending

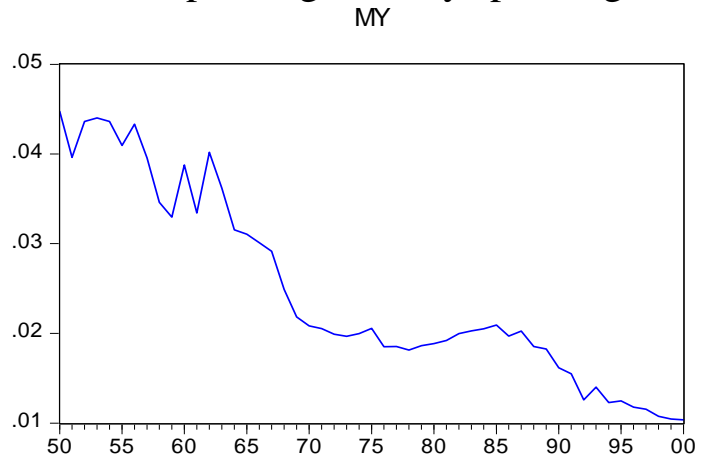

I_M_RATIO

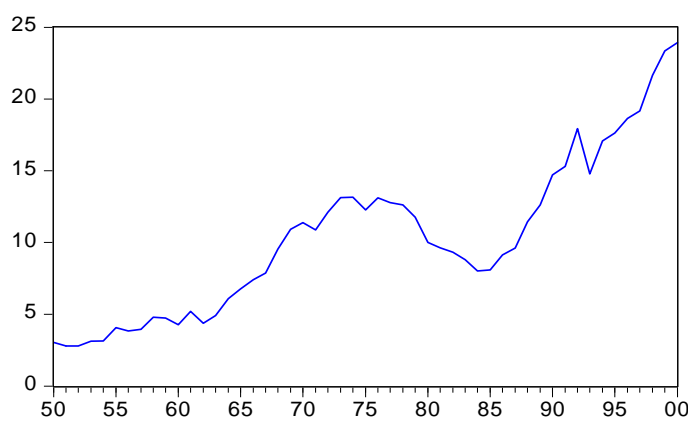

EDU_TOTALY

EDU_TOTAL_M_RATIO
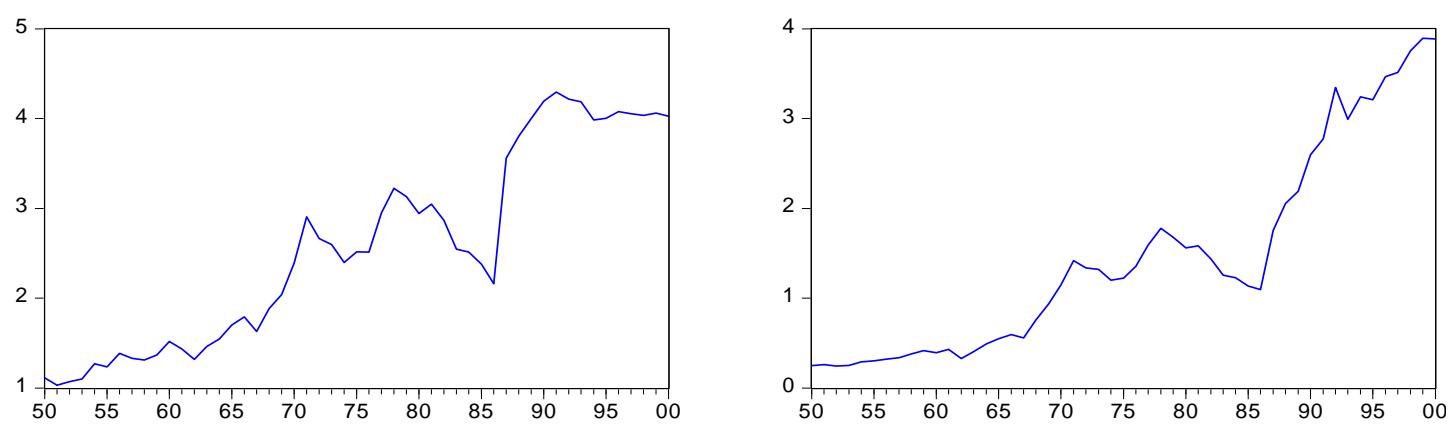
TABLE 1

Descriptive statistics: rates of growth of the main variables.

\begin{tabular}{crrrrrrr} 
& \multicolumn{2}{c}{$\begin{array}{c}\text { WHOLE } \\
(\mathbf{N}=\mathbf{5 0})\end{array}$} & \multicolumn{2}{c}{$\begin{array}{c}\text { FRANCO R. } \\
(\mathbf{N}=\mathbf{2 5})\end{array}$} & \multicolumn{2}{c}{$\begin{array}{c}\text { AF. } \\
\text { FRANCO } \\
(\mathbf{N}=\mathbf{2 5})\end{array}$} \\
& Mean & Std. & Mean & Std. & Mean & Std. \\
\cline { 2 - 8 } DEDU & 8.37 & 13.47 & 10.40 & 9.56 & 6.17 & 16.69 \\
DY & 4.84 & 3.21 & 6.52 & 3.40 & 3.15 & 3.15 \\
DI & 6.39 & 8.45 & 9.47 & 8.71 & 3.30 & 3.30 \\
DP & 4.82 & 3.64 & 6.78 & 3.81 & 2.86 & 2.86 \\
DM & 2.09 & 8.35 & 3.64 & 9.93 & 0.54 & 0.54 \\
DNM & 7.45 & 12.43 & 7.69 & 12.24 & 7.22 & 7.22 \\
\hline
\end{tabular}


TABLE 2

Guns versus butter

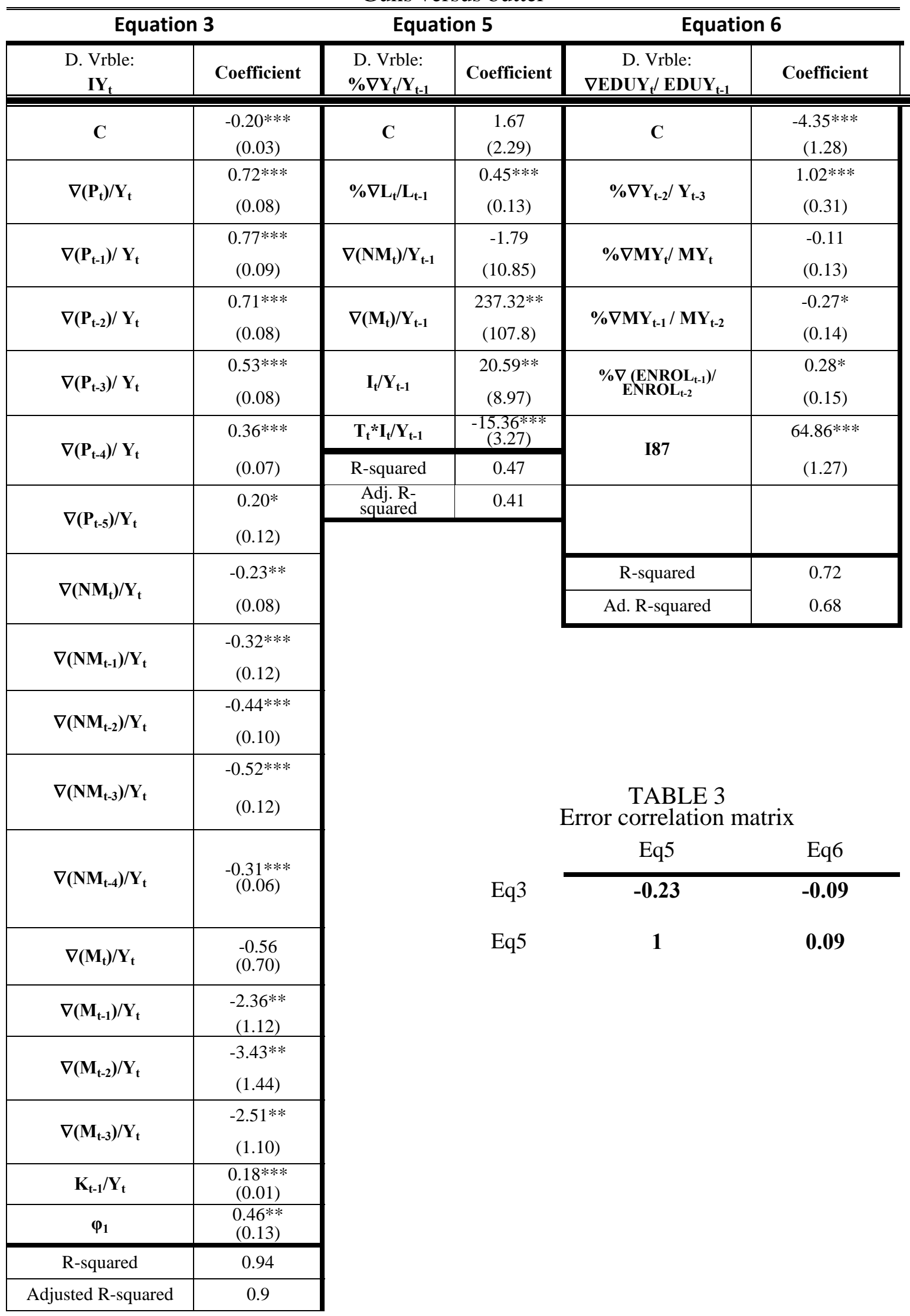


TABLE 4

Guns versus butter (SURE estimator)

\begin{tabular}{|c|c|c|c|c|c|}
\hline \multicolumn{2}{|c|}{ Equation 3} & \multicolumn{2}{|c|}{ Equation 5} & \multicolumn{2}{|c|}{ Equation 6} \\
\hline $\begin{array}{c}\text { D. Vrble: } \\
\mathbf{I Y}_{\mathbf{t}} \\
\end{array}$ & Coefficient & $\begin{array}{l}\text { D. Vrble: } \\
\% \nabla \mathbf{Y}_{\mathbf{t}} / \mathbf{Y}_{\mathrm{t}-1} \\
\end{array}$ & Coefficient & $\begin{array}{c}\text { D. Vrble: } \\
\nabla \text { EDUY }_{\mathrm{t}} / \mathbf{E D U Y}_{\mathrm{t}-1} \\
\end{array}$ & Coefficient \\
\hline C & $\begin{array}{c}-0.11^{* * *} \\
(0.02)\end{array}$ & $\mathbf{C}$ & $\begin{array}{c}1.42 \\
(1.87)\end{array}$ & $\mathbf{C}$ & $\begin{array}{c}-4.37 * * \\
(1.75)\end{array}$ \\
\hline$\nabla\left(\mathbf{P}_{\mathbf{t}}\right) / \mathbf{Y}_{\mathbf{t}}$ & $\begin{array}{c}0.53^{* * *} \\
(0.07)\end{array}$ & $\% \nabla \mathbf{L}_{t} / \mathbf{L}_{t-1}$ & $\begin{array}{c}0.53 * * * \\
(0.13)\end{array}$ & $\% \nabla Y_{t-2} / Y_{t-3}$ & $\begin{array}{c}1.02 * * * \\
(0.30)\end{array}$ \\
\hline$\nabla\left(\mathbf{P}_{\mathrm{t}-1}\right) / \mathbf{Y}_{\mathbf{t}}$ & $\begin{array}{c}0.38^{* * * *} \\
(0.08)\end{array}$ & $\nabla\left(\mathbf{N M}_{\mathbf{t}}\right) / \mathbf{Y}_{\mathbf{t}-1}$ & $\begin{array}{c}-1.21 \\
(13.94)\end{array}$ & $\% \nabla M Y_{t} / M_{t-1}$ & $\begin{array}{l}-0.12 \\
(0.13)\end{array}$ \\
\hline$\nabla\left(\mathbf{P}_{t-2}\right) / \mathbf{Y}_{t}$ & $\begin{array}{c}0.37 * * * \\
(0.08)\end{array}$ & $\nabla\left(\mathbf{M}_{\mathbf{t}}\right) / \mathbf{Y}_{\mathbf{t}-1}$ & $\begin{array}{l}242.29 * \\
(131.9)\end{array}$ & $\% \nabla M Y_{t} / M_{t-1}$ & $\begin{array}{c}-0.26^{* *} \\
(0.13)\end{array}$ \\
\hline$\nabla\left(\mathbf{P}_{\mathrm{t}-3}\right) / \mathbf{Y}_{\mathbf{t}}$ & $\begin{array}{c}0.24 * * * \\
(0.07)\end{array}$ & $I_{t} / Y_{t-1}$ & $\begin{array}{c}21.51^{* * * *} \\
(8.75)\end{array}$ & $\begin{array}{c}\% \nabla\left(\text { ENROL }_{t-1}\right) / \\
\text { ENROL }_{t-2}\end{array}$ & $\begin{array}{c}0.27 \\
(0.17)\end{array}$ \\
\hline$\nabla(\mathbf{D}) / \mathbf{V}$ & $0.14^{*}$ & $\mathbf{T}_{\mathbf{t}}^{*} \mathbf{I}_{\mathbf{t}} / \mathbf{Y}_{\mathrm{t}-1}$ & $\begin{array}{c}-15.34^{* *} \\
(3.09)\end{array}$ & 507 & \\
\hline$V\left(r_{t-4}\right) / r_{t}$ & $(0.08)$ & R-squared & 0.46 & $10 \%$ & $(6.56)$ \\
\hline$\nabla\left(\mathbf{P}_{\mathrm{t}_{5}}\right) / \mathbf{Y}_{\mathrm{t}}$ & & $\begin{array}{l}\text { Adj. R- } \\
\text { squared }\end{array}$ & 0.41 & & \\
\hline & $(0.08)$ & & & & \\
\hline & $-0.11^{*}$ & & & R-squared & 0.72 \\
\hline$V\left(\mathbf{N} \mid \mathbf{V}_{t}\right) / \mathbf{Y}_{t}$ & $(0.06)$ & & & Ad. R-squared & 0.68 \\
\hline$\nabla\left(\mathbf{N M}_{\mathbf{t}-1}\right) / \mathbf{Y}_{\mathbf{t}}$ & $\begin{array}{r}-0.08 \\
(0.07) \\
\end{array}$ & & & & \\
\hline$\nabla\left(\mathbf{N M}_{\mathbf{t}-2}\right) / \mathbf{Y}_{\mathbf{t}}$ & $\begin{array}{l}-0.13 \\
(0.08)\end{array}$ & & & & \\
\hline$\nabla\left(\mathbf{N M}_{\mathbf{t}-3}\right) / \mathbf{Y}_{\mathbf{t}}$ & $\begin{array}{c}-0.19 * * \\
(0.09)\end{array}$ & & & & \\
\hline$\nabla\left(\mathbf{N M}_{\mathrm{t}-4}\right) / \mathbf{Y}_{\mathbf{t}}$ & $\begin{array}{l}-0.09 \\
(0.09)\end{array}$ & & & & \\
\hline$\nabla\left(\mathbf{M}_{\mathbf{t}}\right) / \mathbf{Y}_{\mathbf{t}}$ & $\begin{array}{l}-0.42 \\
(0.59)\end{array}$ & & & & \\
\hline$\nabla\left(\mathbf{M}_{\mathrm{t}-1}\right) / \mathbf{Y}_{\mathbf{t}}$ & $\begin{array}{c}-1.84 * * \\
(0.73)\end{array}$ & & & & \\
\hline$\nabla\left(\mathbf{M}_{\mathbf{t}-2}\right) / \mathbf{Y}_{\mathbf{t}}$ & $\begin{array}{c}-1.61^{* *} \\
(0.76)\end{array}$ & & & & \\
\hline$\nabla\left(\mathbf{M}_{\mathbf{t}-3}\right) / \mathbf{Y}_{\mathbf{t}}$ & $\begin{array}{l}-1.31^{*} \\
(0.70)\end{array}$ & & & & \\
\hline $\mathbf{K}_{\mathbf{t - 1}} / \mathbf{Y}_{\mathbf{t}}$ & $\begin{array}{c}0.09 * * * \\
(0.02)\end{array}$ & & & & \\
\hline$\varphi_{1}$ & $\begin{array}{l}0.53 * * \\
(0.02)\end{array}$ & & & & \\
\hline R-squared & 0.95 & & & & \\
\hline Adjusted R-squared & 0.92 & & & & \\
\hline
\end{tabular}

